\title{
SISTEM INFORMASI PEMELIHARAAN TEMPAT IBADAH DALAM EFEKTIFITAS PENYALURAN DANA SUMBANGAN
}

\author{
${ }^{1}$ Rengga Asmara, ${ }^{2}$ Ahmad Syauqi Ahsan, ${ }^{3}$ Muhammad Odi Rachmawan \\ 1,2,3 Teknik Informatika, Departemen Teknik Informatika dan Komputer \\ Politeknik Elektronika Negeri Surabaya \\ Kampus PENS, Jalan Raya ITS, Keputih, Sukolilo, Surabaya, 60111 \\ Email: rengga@pens.ac.id,syauqi@pens.ac.id,odirachmawan@gmail.com
}

(Diterima: 27 November 2019,direvisi: 12 Januari 2020,disetujui: 24 Januari 2020)

\begin{abstract}
In one region, a worship place is very crucial for societies as a place of their religious activities. Other than that, it is also as a place of worship and promoting religion. A healthy worship place has managers and some active donators in its management. Therefore, its condition will always be protected. In contrast, there are still many small worship places such as Musholla, and Langgar which are not well protected. They sometimes are not supported by the proper management where it causes a lack of donators. For that reason, it needs a system to help the management partners propose the worship place equipment. Through this system, the donators enable to choose which place of worship that needs help. Then, the admin of the information system becomes a mediator to distribute the donations. This system, on the other hand, helps the management partners to display their worship places' needs to the donators. Otherwise, the donators can also easily search the worship place which needs funding. Hence, this system is aimed to help the place of worship's management partners to find some funds without any confusion. Besides, this system can be as a connector between the managing partners and the donators in managing the worship place, so all the worship places can be managed equally.
\end{abstract}

Keywords : information system, worship place, donator, management partner.

\begin{abstract}
ABSTRAK
Tempat ibadah merupakan sarana tempat yang penting bagi masyarakat dalam menjalankan kegiatan keagamaan di suatu daerah. Selain sebagai sarana tempat kegiatan keagamaan, juga sebagai tempat penyiaran agama dan tempat melakukan ibadah. Tempat ibadah yang sehat memiliki pengelola dan penyantun yang aktif dalam pengelolaannya, sehingga kondisi dari tempat ibadah tersebut selalu terpelihara. Namun pada kenyataannya masih banyak dijumpai tempat ibadah kecil seperti musholla, langgar yang terkadang tidak terawat dengan baik hal ini dikarenakan tidak didukung dengan pengelolaan yang baik sehingga susah dalam mendapatkan donatur untuk tempat ibadah tersebut. Oleh karena itu dibutuhkan suatu sistem yang bisa membantu mengelola tempat ibadah secara merata dimana mitra pengelola tempat ibadah bisa mengajukan kebutuhan ke sistem, donatur bisa memilih dan melakukan donasi ke tempat ibadah yang membutuhkan, dengan admin sebagai perantara melalui sistem informasi pemeliharaan tempat ibadah dalam efektifitas penyaluran dana sumbangan. Sistem ini menampilkan mitra pengelola tempat ibadah yang sedang membutuhkan dana. Dengan sistem ini, mitra pengelola tempat ibadah yang sedang membutuhkan dana untuk tempat ibadahnya dapat menunjukkan kebutuhan yang diperlukan ke donatur yang bersedia, begitu juga dengan donatur yang bisa tahu dan melakukan donasi ke tempat ibadah yang sedang membutuhkan dana sehingga mitra pengelola tempat ibadah tidak bingung mencari dana untuk memenuhi kebutuhan tempat ibadahnya. Dengan adanya sistem ini dapat menjalin hubungan antara mitra dan donatur dalam mengelola tempat ibadah sehingga pengelolaan tempat ibadah bisa merata.
\end{abstract}

Kata Kunci: sistem informasi, tempat ibadah, donatur, mitra pengelola.

\section{PENDAHULUAN}

Tempat ibadah bagi pemeluk agama di suatu tempat merupakan sarana keagamaan yang penting. Selain sebagai simbol "keberadaan" pemeluk agama, tempat ibadah juga digunakan sebagai tempat

Rengga Asmara, Sistem Informasi Pemeliharaan Tempat Ibadah Dalam Efektifitas Penyaluran Dana Sumbangan 
melakukan suatu peribadatan dan sekaligus tempat penyiaran agama. Artinya, manfaat tempat ibadah sangat diharapkan akan dapat memberikan dorongan yang kuat dan terarah bagi para jamaahnya agar kehidupan spiritual keberagamaan bagi pemeluk agama tersebut selalu menjadi lebih baik, disamping sebagai tempat peribadahan. Tempat ibadah yang sehat memiliki pengelola dan penyantun yang aktif dalam pengelolaannya, sehingga kondisi dari tempat ibadah tersebut selalu terpelihara[1]. Namun masih banyak tempat ibadah kecil seperti musholla, langgar yang terkadang tidak didukung dengan pengelolaan dan yang baik[2].Dalam proses pengelolaannya, tempat ibadah yang kecil seperti musholla atau langgar justru terkadang kurang diperhatikan oleh orang-orang sekitar, dan terkadang donaturdonatur yang aktif lebih tahu dan memilih menyalurkan dana sumbangan ke tempat ibadah yang bisa dibilang sudah baik pengelolaannya. Akan tetapi tempat ibadah tetaplah tempat ibadah, baik tempat ibadah yang kecil maupun yang besar sama-sama perlu diperhatikan pengelolaannya[3]. Oleh karena itu dibutuhkan sistem yang bisa meratakan pengelolaan tempat ibadah yang kecil maupun besar sehingga nantinya tempat ibadah yang jarang atau susah mendapatkan donasi untuk kebutuhannya, bisa ikut mendapatkan dana untuk mengelola kebutuhan tempat ibadah tersebut.

Sistem yang akan dibuat ini bertujuan untuk mempermudah pengelola dalam melaporkan kekurangan fasilitas atau kebutuhan pemeliharaan dalam sebuah tempat ibadah. Kekurangan fasilitas atau kebutuhan pemeliharaan tempat ibadah bisa dilaporkan melalui gambar situasi kondisi terkini dan jumlah uang yang dibutuhkan.Di sisi lain donatur yang ingin melakukan donasi bisa memilih kebutuhan tempat ibadah mana yang akan diberi donasi. Sehingga nantinya dapat tindak lanjutuntuk dilakukan pemenuhan kebutuhan atas pengelola tempat ibadah yang bersangkutan. Jika kebutuhan tempat ibadah sudah terpenuhi, donatur juga bisa melihat hasil dari donasinya ke tempat ibadah tersebut dengan melihat update situasi kondisi terbaru setelah menerima donasi.

\section{TINJAUAN PUSTAKA}

Sistem adalah suatu jaringan kerja dari kumpulan prosedur yang berkumpul bersama-sama dan saling terkait untuk menyelesaikan suatu target tertentu atau untuk melakukan suatu kegiatan [4]. Sistem adalah sekelompok komponen yang saling terkait, saling bekerja sama untuk mencapai tujuan bersama dengan menerima masukan serta menghasilkan keluaran dalam proses informasi yang teratur [5]. Informasi adalah data yang diolah menjadi bentuk tertentu yang lebih bermanfaat dan lebih memiliki arti bagi yang menerimanya [4]. Informasi yang berguna bagi pengambilan keputusan saat ini atau mendatang, merupakan data yang telah diproses menjadi suatu bentuk yang berarti bagi para penerimanya. Sistem Informasi (SI) untuk mendukung operasi dan manajemen adalah gabungan dari teknologi informasi dan aktivitas orang yang menggunakan teknologi tersebut. Dalam arti yang sangat luas, istilah sistem informasi yang sering dipakai mengacu kepada interaksi antara teknologi, data, proses algoritmik, dan para penggunanya. Dalam pengertian ini, istilah ini dipakai untuk mengacu tidak hanya pada pemakaian organisasi teknologi informasi dan komunikasi (TIK), tetapi juga sebagai cara agar orang tersebut berinteraksi dengan teknologi ini dalam upaya mendukung proses bisnis. Sistem Informasi adalah gabungan yang teratur antara manusia, perangkat lunak, perangkat keras, jaringan komunikasi dan sumber data, dalam upayanya untuk mengumpulkan, mengubah, dan menyebarkan informasi dalam organisasi [5].

Inspirasi kemunculan melakukan kegiatan crowdfunding berasal dari konsep micro-finance[7]dan crowdsourcing [8]. Crowdfunding adalah praktik untuk berbagai jenis usaha dalam penggalangan dana, yang dananya diperoleh dari sumbangan masyarakat banyak, baik berupa kegiatan, bisnis, atau ide produk, dan sering kali mempunyai imbal balik berupa jasa atau barang [6]. Jenis proyek yang memakai metode crowdfunding dapat diklasifikasikan untuk mempermudah kategori atau membedakan setiap proyek yang sedang dijalani [9]. Menurut Hemer, terdapat kategori proyek sebagai berikut: Commercial background or objectives of initiative or project: Not-for-profit, For profit, Intermediate dan Original organizational embeddedness: Independent and single, Embedded, Startup. Penggalangan dana menggunakan crowdfunding sendiri umumnya dijalankan dalam bentuk suatu platform aplikasi berbasis website. Terdapat empat jenis website crowdfunding berdasarkan sistemnya, yaitu equity based, donation based, lending based, dan rewards-based. 
Dalam pembuatannya nanti akan melalui HTML dimana HTML (Hypertext Markup Languange) adalah bahasa yang digunakan untuk menulis halaman web. HTML merupakan pengembangan dari Standard Generalized Markup Language (SGML), yaitu standar pemformatan dokumen teks. HTML pada dasarnya dirancang untuk tidak tergantung pada suatu sistem operasi tertentu, yang merupakan dokumen ASCII atau teks biasa [10]. Untuk kerangka kerjanya menggunakan framework Yii dimana Yii merupakan Framework (kerangka kerja) PHP berkinerja tinggi untuk pengembangan aplikasi web berskala besar berbasis komponen. Yii juga mampu meningkatkan kecepatan pengembangan secara signifikan dan dalam pemrograman web menyediakan reusability maksimum [11]. Yii menggunakan pola desain MVC (model-view-controller), yang diadopsi secara menyeluruh dalam pemrograman web. MVC bertujuan agar para pengembang dapat lebih mudah mengubah setiap bagian tanpa mempengaruhi yang lain, dengan cara memisahkan antara logika bisnis dari pertimbangan antar muka pengguna [12]. CSS (Cascading Style Sheet) adalah standard pembuatan dan pemakaian style untuk dokumen terstruktur, CSS digunakan untuk mempersingkat penulisan tag HTML sehingga tidak terjadi pengulangan tulisan, seperti text, font, color, dan table menjadi lebih ringkas [13].PHP sendiri sebenarnya merupakan sebuah bahasa scripting tingkat tinggi yang dipasang pada dokumen HTML, merupakan singkatan dari "Hypertext Preprocessor". MySQL adalah sebuah perangkat lunak yang multithread dan multi-user untuk system manajemen basis data SQL (DBMS). MySQL adalah implementasi dari sistem manajemen basis data relasional (RDBMS) [14].

Sebagai perantara dalam melakukan penggalangan dana pada aplikasi crowdfunding berbasis website dan facebook application, dikembangkan suatu sistem tertentu untuk membangun aplikasi crowdfunding berbasis website dan Facebook application. Aplikasi tersebut diharapkan akan menaikkan tingkat publikasi dan memiliki koneksi langsung dengan aplikasi Facebook. Bentuk model share dan login dengan akun Facebook merupakan jenis koneksi yang sering digunakan. Untuk mencegah tingkat penipuan, digunakan pula fitur seperti report campaign dan campaign validation [3]. Fitur yang lain, juga dapat membantu untuk meningkatkan publikasi yaitu newsletter dan follow.

Sedangkan pada sistem informasi pemeliharaan tempat ibadah dalam efektifitas penyaluran dana sumbangan yang akan dibuat, yaitu sebagai perantara antara pihak mitra pengelola tempat ibadah yang sedang membutuhkan dengan donatur yang akan melakukan donasi yang dikontrol oleh admin yayasan tertentu. Nantinya sistem dapat diakses oleh siapa saja melalui web dimana terdapat fitur pendaftaran, pengajuan kebutuhan oleh mitra, donasi oleh donatur dan update situasi kondisi terbaru dari mitra yang bisa dilihat secara transparan oleh siapapun.

\section{METODE PENELITIAN}

Tujuan penelitian ini adalah membangun sistem yang bisa melakukan pemerataan dalam pengelolaan kebutuhan tempat ibadah. Untuk mencapai tujuan penelitian tersebut dilakukan langkahlangkah pengembangan sistem informasi pemeliharaan tempat ibadah dalam efektifitas penyaluran dana sumbangan dapat dilihat pada Gambar 1.

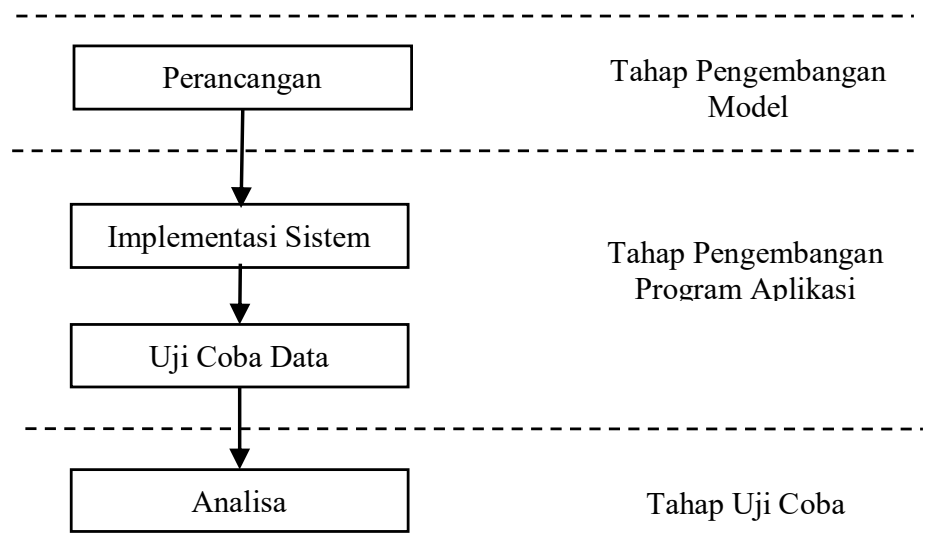

Gambar 1 Langkah pengembangan sistem 
1. Perancangan Sistem

Tahap ini meliputi perancangan sistem, tahap yang paling penting dimana bentuk awal atau prototype akan diimplementasikan. Pada tahapan ini dilakukan perancangan desain sistem berdasarkan proses bisnis penyaluran dana sumbangan tempat ibadah saat ini dan kebutuhan sistem yang akan datang melalui blok diagram sistem, usecase dan database relasional. Tahap perancangan sistem juga merupakan tahap pembuatan desain tampilanuserinterface yang nantinya muncul dalam aplikasi.

2. Implementasi Sistem

Pembuatan sistem yang akan digunakan untuk membuat sistem informasi ini yaitu menggunakan tools framework Yii dengan design pattern MVC melalui database MySQL dan bahasa pemrograman PHP. Hasil tampilan dari sistem ini diantaranya adalah halaman tampilan awal, halaman login, form registrasi donatur, form registrasi mitra, form konfirmasi registrasi mitra, form pengajuan kebutuhan, form pendanaan, form konfirmasi kebutuhan, form pembaruan situasi kondisi, halaman lihat pembaruan situasi kondisi, dan form pemilihan kategori

3. Uji Coba Data dan Analisa

Setelah melakukan pembuatan sistem informasi, dilakukan uji coba sistem dan analisa yang dihasilkan. Hal tersebut digunakan untuk mengetahui sejauh apa sistem yang dibuat ini telah bekerja sesuai dengan kriteria yang telah ditentukan sebelumnya. Salah satu metode atau acuan untuk menentukan kualitas dari suatu software adalah ISO 9126 yang dibuat oleh International Electrotechnical Commision (IEC) dan International Organization for Standardization (ISO [15]. ISO 9126 mendefinisikan model, karakteristik mutu, kualitas produk perangkat lunak, dan matrik terkait yang digunakan untuk menetapkan dan mengevaluasi kualitas suatu software. Beberapa faktor yang menentukan kualitas software menurut ISO 9126 adalah Functionality (Fungsionalitas), merupakan kemampuan perangkat lunak ketika digunakan dalam kondisi tertentu untuk menyediakan fungsi sesuai kebutuhan pengguna danUsability (Kebergunaan), merupakan kemampuan perangkat lunak ketika digunakan dalam kondisi tertentu untuk digunakan, dipahami, dipelajari, dan menarik bagi pengguna.

\section{HASIL DAN PEMBAHASAN}

\section{Perancangan Sistem}

Perancangan sistem terbagi menjadi beberapa yaitu Perancangan Diagram Blok Sistem, Perancangan Diagram Use Case, dan Perancangan Database (Entity Relationalship Diagram).

a. Perancangan Diagram Blok Sistem

Blok diagram sistem menggambarkan dasar alur yang akan digunakan untuk jalannya aplikasi ini. Blok diagram sistem dari Sistem Informasi Pemeliharaan Tempat Ibadah Dalam Efektifitas Penyaluran Dana Sumbangandapat dilihat pada Gambar 2.

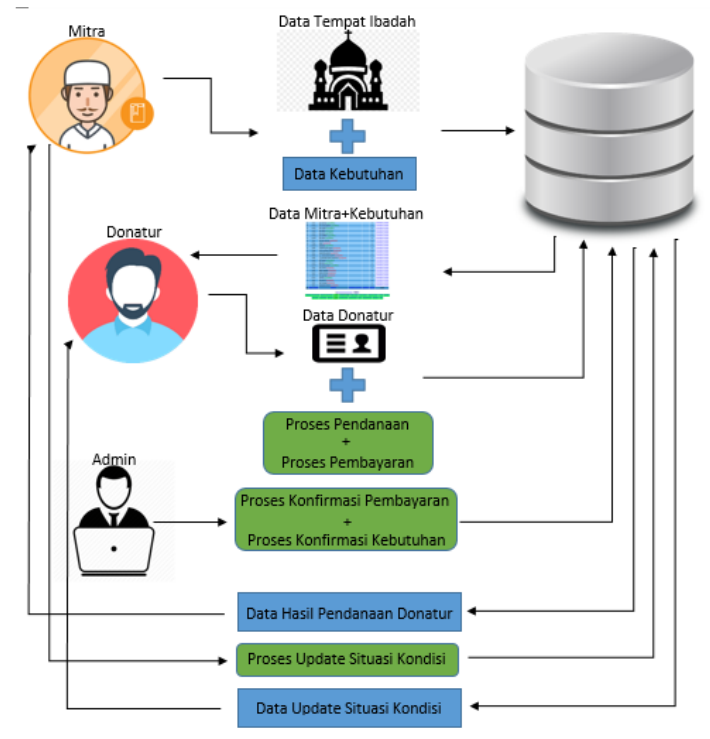

Gambar 2 Blok diagram sistem 
Penjelasan secara detail dari blok diagram Sistem Informasi Pemeliharaan Tempat Ibadah Dalam Efektifitas Penyaluran Dana Sumbangan adalah sebagai berikut:

Mitra Tempat Ibadah adalah mitra yang mewakili suatu tempat ibadah, disini mitra bisa mendaftar atau memasukkan data tempat ibadah beserta kebutuhan yang dibutuhkan oleh tempat ibadah ke dalam sistem. Jika kebutuhan sudah jatuh tempo atau dikonfirmasi maka mitra akan mendapatkan dana atau data hasil pendanaan donatur. Setelah mendapatkan dana, mitra bisa melakukan update situasi kondisi terbaru tempat ibadah dari dana yang sudah diterima.

Donatur adalah orang yang melakukan donasi ke suatu tempat ibadah melalui sistem dimana donatur dapat melihat data tempat ibadah beserta kebutuhannya di dalam sistem dan jika ingin melakukan donasi, donatur mendaftar untuk melakukan pendanaan beserta pembayaran atas tempat ibadah yang akan didanai. Jika kebutuhan mitra tempat ibadah yang didanai oleh donatur telah jatuh tempo, donatur bisa melihat hasil update situasi kondisi terbaru tempat ibadah dari dana yang terkumpul.

Admin adalah bagian dari administrasi sistem yang dapat melakukan konfirmasi pembayaran yang sudah dilakukan donatur serta melakukan konfirmasi kebutuhan mitra tempat ibadah jika sudah jatuh tempo ke dalam sistem.

b. Perancangan Diagram Use Case

Use case diagram akan menjelaskan tentang apa saja yang dapat dilakukan oleh aktor atau pengguna dalam sistem. Use case diagram dari Sistem Informasi Pemeliharaan Tempat Ibadah Dalam Efekifitas Penyaluran Dana Sumbangan dapat dilihat pada Gambar 3.

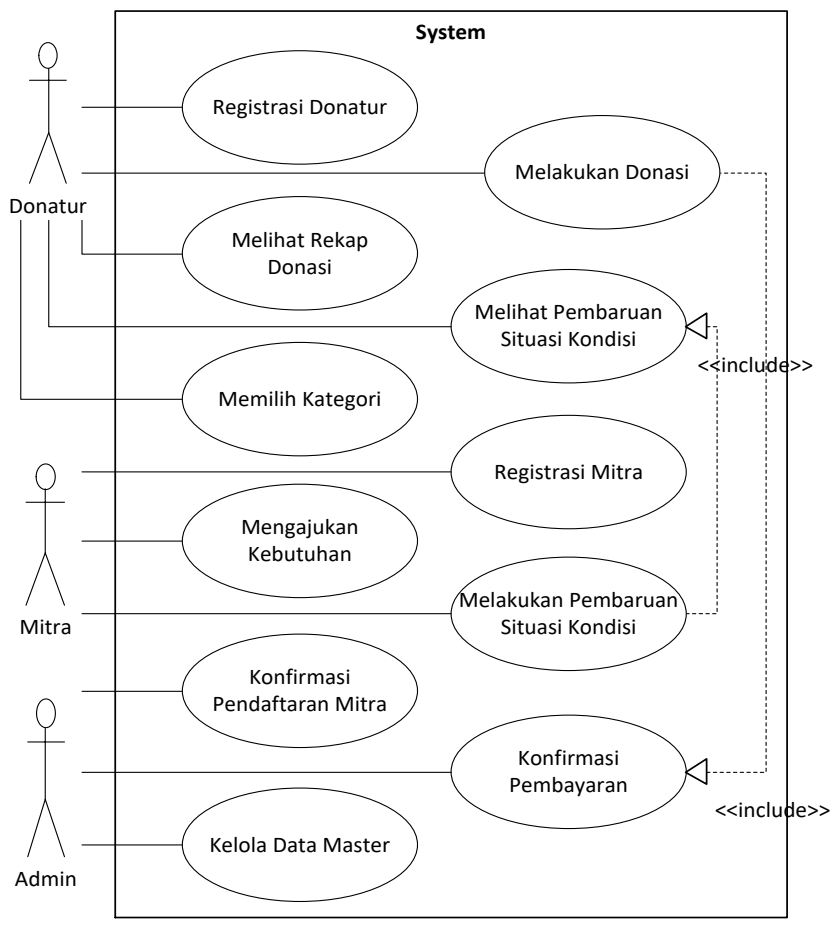

Gambar 3 Use case diagram

Use case diagram sistem informasi pemeliharaan tempat ibadah dalam efektifitas penyaluran dana sumbangan diatas memiliki 9 proses besar dan 3 aktor. Berikut adalah aktor yang terlibat dalam sistem informasi urun daya pemeliharaan tempat ibadah untuk meningkatkan efektifitas penyaluran dana sumbangan dan peran yang dapat dilakukan dalam sistem.

AdminMerupakan aktor yang berperan untuk mengelola user pengguna sistem. Dimana nantinya admin bisa melakukan login untuk melakukan proses konfirmasi registrasi mitra, dan konfirmasi pembayaran yang sudah dilakukan oleh donatur.

Donatur merupakan aktor yang berperan untuk melakukan pendanaan pemeliharaan terhadap suatu mitra pengelola tempat ibadah tertentu. Dimana nantinya donatur bisa melakukan registrasi dan login 
untuk melakukan proses pendanaan pembayaran suatu mitra pengelola tempat ibadah yang sudah dipilih serta memilih kategori untuk notifikasi donatur.

Mitra merupakan aktor yang terlibat dalam suatu pendanaan pemeliharaan tempat ibadah. Dimana nantinya mitra bisa melakukan registrasi dan login untuk melakukan proses pengajuan kebutuhan, dan proses pembaruan situasi kondisi atas pendanaan yang sudah dilakukan oleh para donator terhadap mitra yang bersangkutan.

c. Perancangan Database (Entity Relationalship Diagram)

Rancangan database dalam sistem ini akan digambarkan dengan Entity Relationalship Diagram, merupakan model yang menggambarkan isi dan hubungan data dalam suatu basis data ke dalam bentuk entitas, atribut, serta relationship antar entitas. Entity Relationalship diagram dari Sistem Informasi Pemeliharaan Tempat Ibadah Dalam Efektifitas Penyaluran Dana Sumbangan dapat dilihat pada Gambar 4.

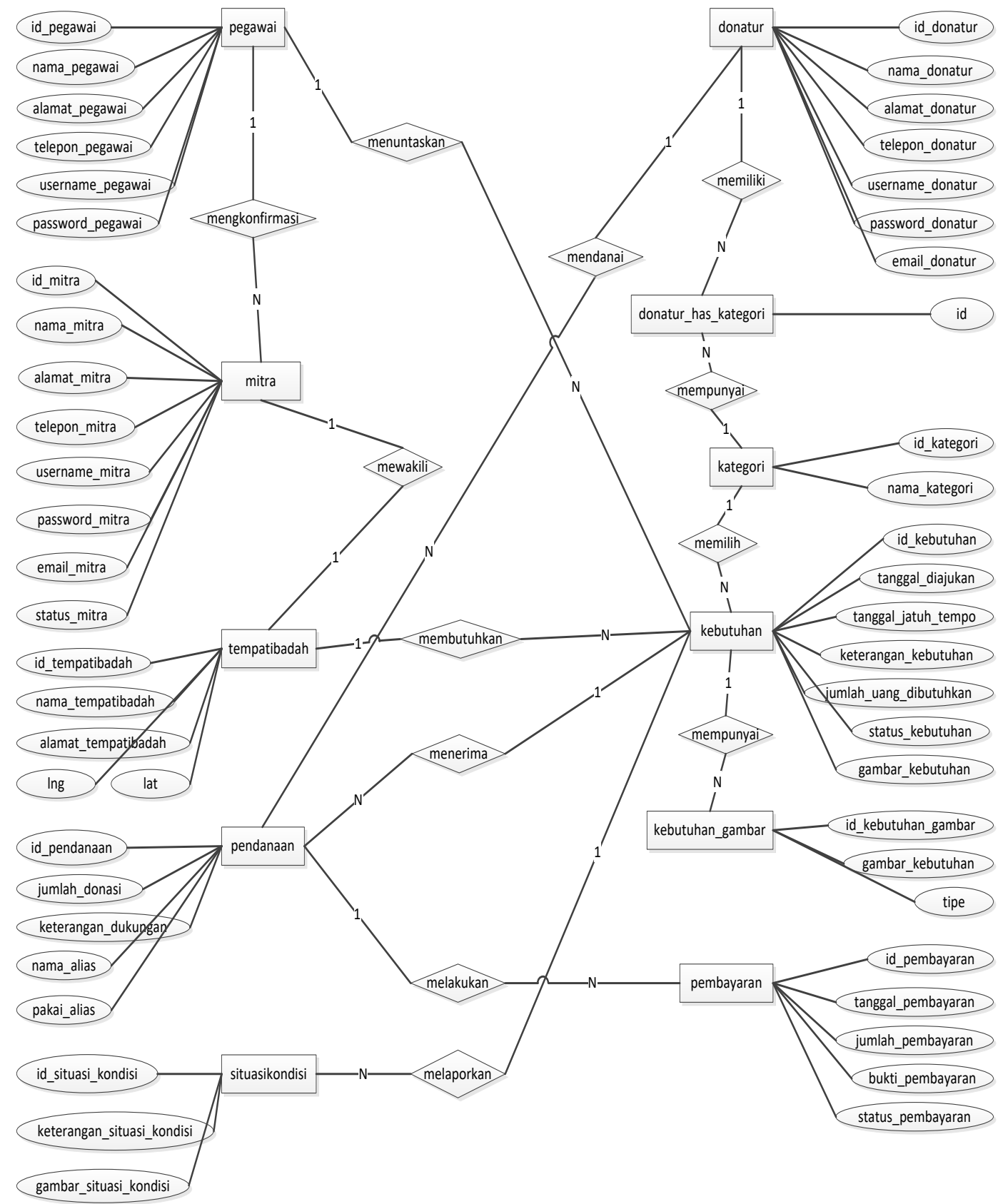

Gambar 4 Entity relationship diagram 
Pada Entity Relationalship diagram dari Sistem Informasi Pemeliharaan Tempat Ibadah Dalam Efektifitas Penyaluran Dana Sumbangan terdapat 11 entitas yang saling berhubungan dan menggambarkan sistem yang akan dibuat diantaranya adalah pegawai, mitra, donatur, kategori, donatur_has_kategori, tempat_ibadah, kebutuhan, kebutuhan_gambar, pendanaan, pembayaran, situasi_kondisi.

\section{Implementasi Sistem}

Berikut ini merupakan Implementasi Sistem Informasi Pemeliharaan Tempat Ibadah Dalam Efektifitas Penyaluran Dana Sumbangan :

A. Implementasi sistem pada semua user

\section{Implementasi Fitur Login}

Implementasi antarmuka ini akan menunjukkan tampilan pada halaman awal sistem. Halaman awal form login dapat dilihat pada Gambar 5.

\section{System Login}

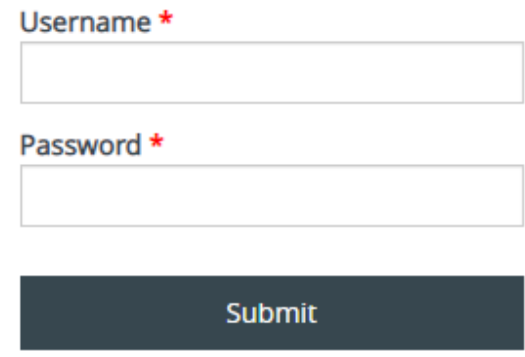

\section{Gambar 5 Form login}

Pada halaman awal, ketika pengguna mengakses sistem akan ditampilkan halaman form login digunakan user yang sudah memiliki akun untuk memasukkan username dan password agar dapat masuk ke sistem dengan hak akses masing - masing user.

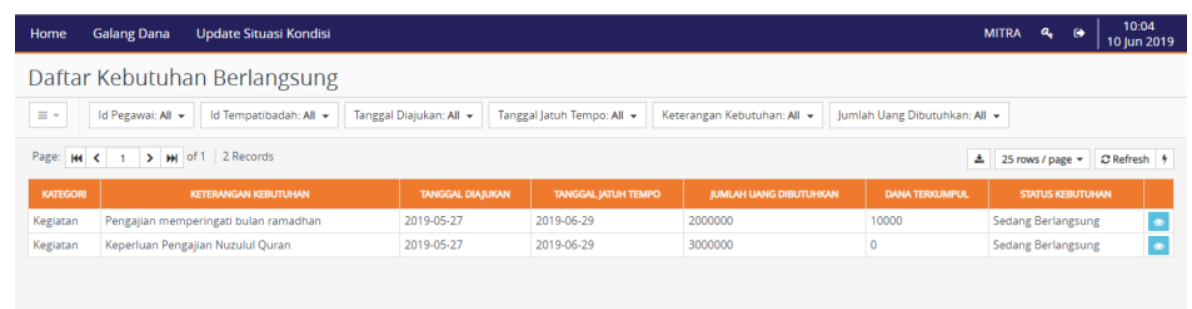

Gambar 6 Halaman home mitra

Setelah berhasil login sebagai mitra maka user akan masuk Halaman Home Mitra dimana user bisa melakukan lihat galang dana yang berlangsung, galang dana, dan update situasi kondisi. Halaman Home Mitra dapat dilihat pada Gambar 6.

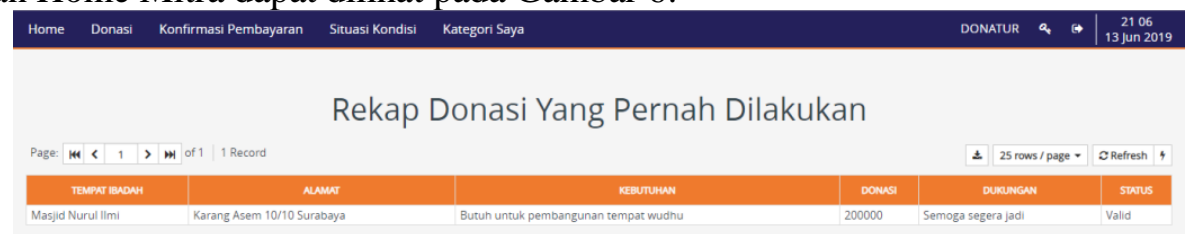

\section{Gambar 7 Halaman home donatur}

Setelah berhasil login sebagai donatur maka user akan masuk Halaman Home Donatur dimana user bisa melihat kebutuhan tempat ibadah, memilih kategori, melakukan donasi, konfirmasi 
pembayaran, dan melihat situasi kondisi terbaru. Halaman Home Donatur dapat dilihat pada Gambar 7.

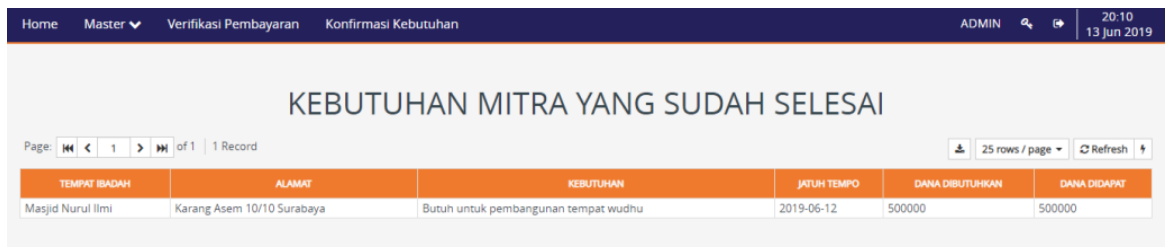

\section{Gambar 8 Halaman home admin}

Setelah berhasil login sebagai admin maka user akan masuk Halaman Home Admin dimana user bisa melihat situasi kondisi terbaru, melihat master, melakukan verifikasi pembayaran, dan konfirmasi kebutuhan. Halaman Home Admin dapat dilihat pada Gambar 8.

B. Implementasi sistem pada user mitra

1. Implementasi Fitur Registrasi Mitra

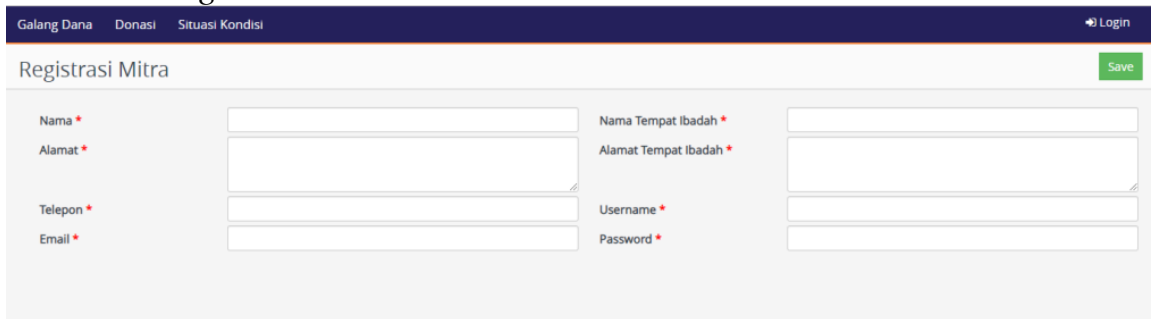

\section{Gambar 9 Halaman Registrasi Mitra}

Halaman Registrasi Mitra merupakan halaman awal untuk mitra ketika ingin mendaftar ke dalam sistem. Tampilan halaman registrasi mitra dilihat pada Gambar 9.

\section{Implementasi Fitur Galang Dana}

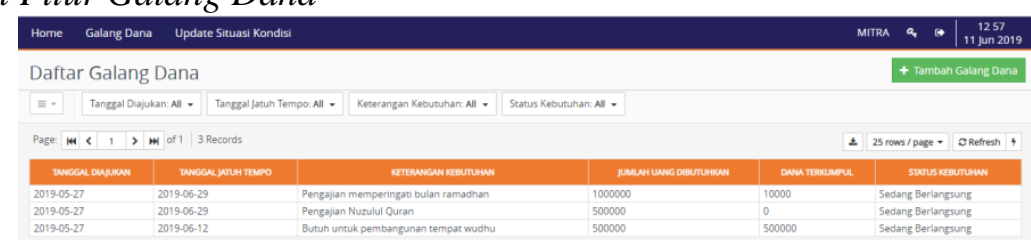

\section{Gambar 10 Halaman Daftar Galang Dana}

Halaman daftar galang dana ini dapat diakses oleh mitra, pada halaman ini akan ditampilkan list daftar kebutuhan yang statusnya sedang berlangsung maupun sudah selesai. Implementasi halaman daftar galang dana dapat dilihat pada Gambar 10.

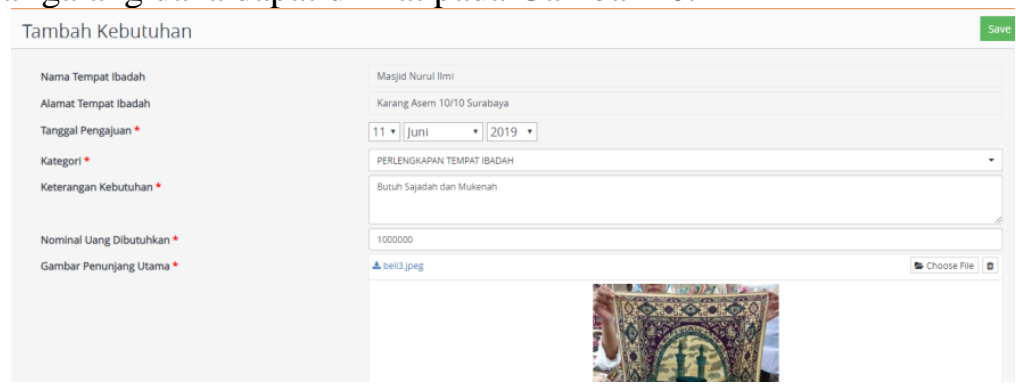




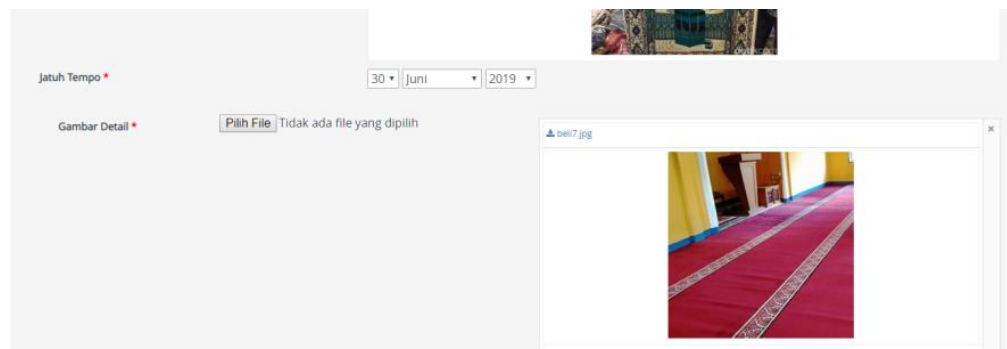

Gambar 2 Halaman tambah kebutuhan

Pada halaman galang dana ini juga dapat melakukan tambah galang dana atau menambahkan kebutuhan baru yang akan diajukan mitra mulai dari kategori, keterangan kebutuhan, jumlah uang dibutuhkan, gambar penunjang serta tanggal jatuh tempo pengajuan kebutuhan akan berakhir. Implementasi halaman tambah kebutuhan dapat dilihat pada Gambar 11.

3. Implementasi Fitur Update Situasi Kondisi

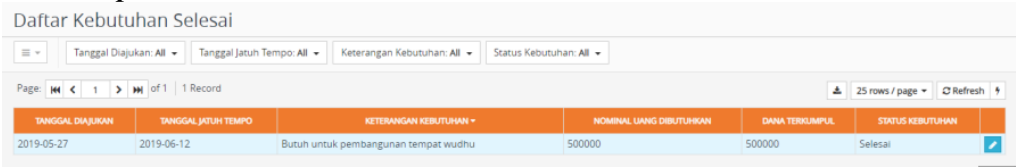

Gambar 3 Halaman daftar kebutuhan selesai

Halaman daftar kebutuhan selesai ini dapat diakses oleh mitra, pada halaman ini akan ditampilkan list daftar kebutuhan selesai yaitu list daftar kebutuhan yang dananya sudah dicairkan oleh admin dan diberikan kepada mitra yang bersangkutan. Implementasi halaman daftar kebutuhan selesai dapat dilihat pada Gambar 12.

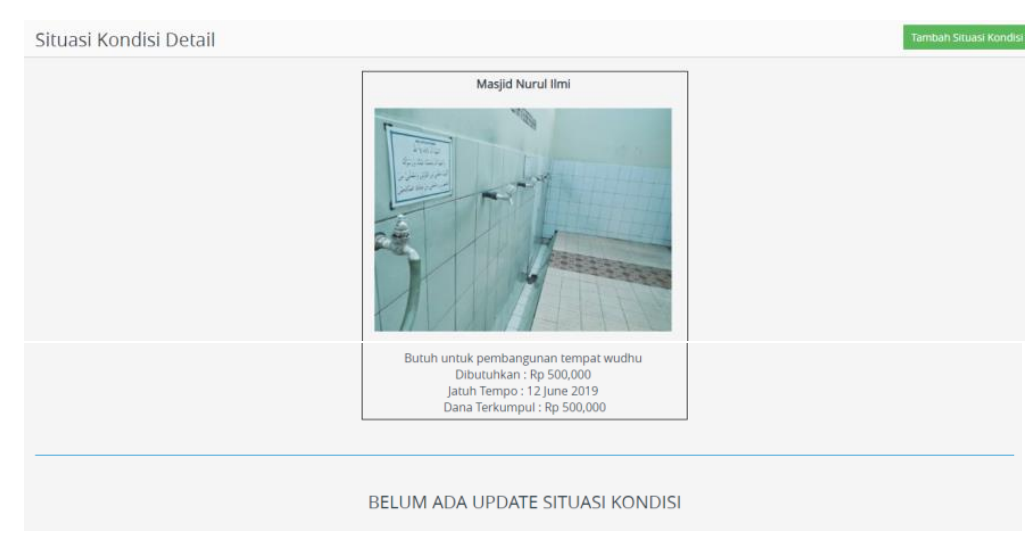

\section{Gambar 4 Halaman Situasi Kondisi Detail}

Pada halaman daftar kebutuhan selesai juga dapat melihat situasi kondisi detail dari kebutuhan selesai yang dipilih yaitu update siituasi kondisi terbaru. Implementasi halaman situasi kondisi detail dapat dilihat pada Gambar 13.

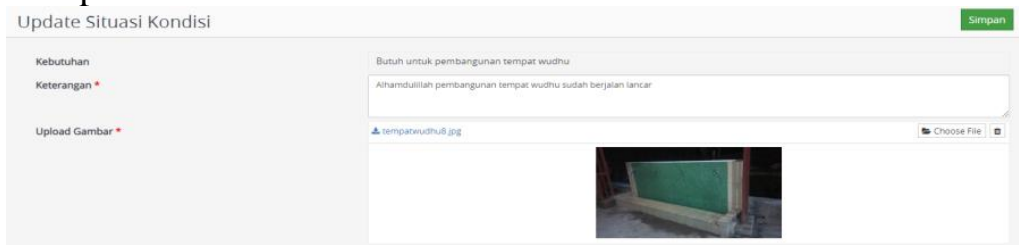

\section{Gambar 5 Halaman Update Situasi Kondisi}

Pada halaman situasi kondisi detail, mitra bisa melakukan tambah situasi kondisi yaitu mengupdate situasi kondisi terbaru dari suatu kebutuhan selesai yang dipilih. Mitra bisa melaporkan keterangan situasi kondisi terbaru beserta gambar penunjangnya. Implementasi halaman update situasi kondisi dapat dilihat pada Gambar 14. 
C. Implementasi sistem pada user donatur

1. Implementasi Fitur Registrasi Donatur

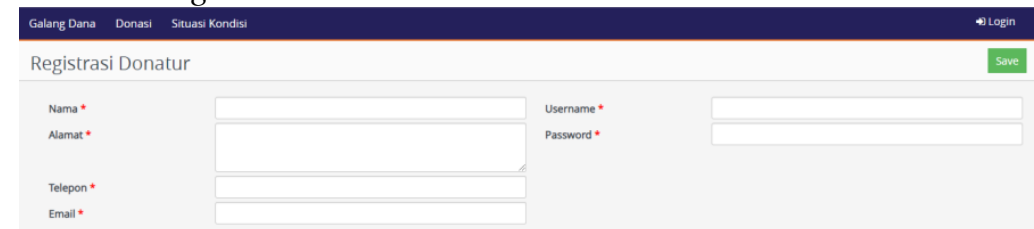

Gambar 6 Halaman Registrasi Donatur

Halaman Registrasi Donatur merupakan halaman awal untuk donatur ketika ingin mendaftar ke dalam sistem. Tampilan halaman registrasi donatur dilihat pada Gambar 15.

\section{Implementasi Fitur Donasi}

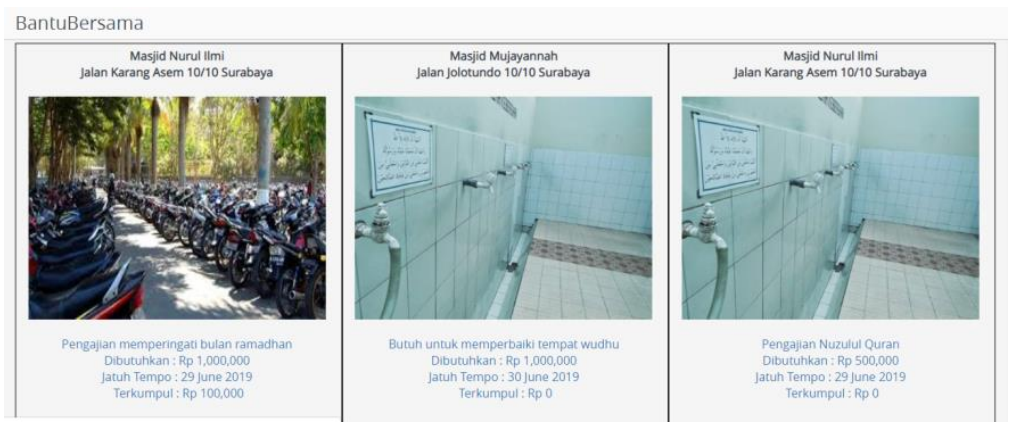

Gambar 7 Halaman Donasi

Halaman donasi ini dapat diakses oleh donatur. Pada halaman ini ditampilkan beberapa tempat ibadah yang mengajukan kebutuhan disertai keterangan kebutuhan, dana dibutuhkan, tanggal jatuh tempo kebutuhan tersebut berakhir dan dana yang terkumpul. Implementasi halaman donasi dapat dilihat pada Gambar 16

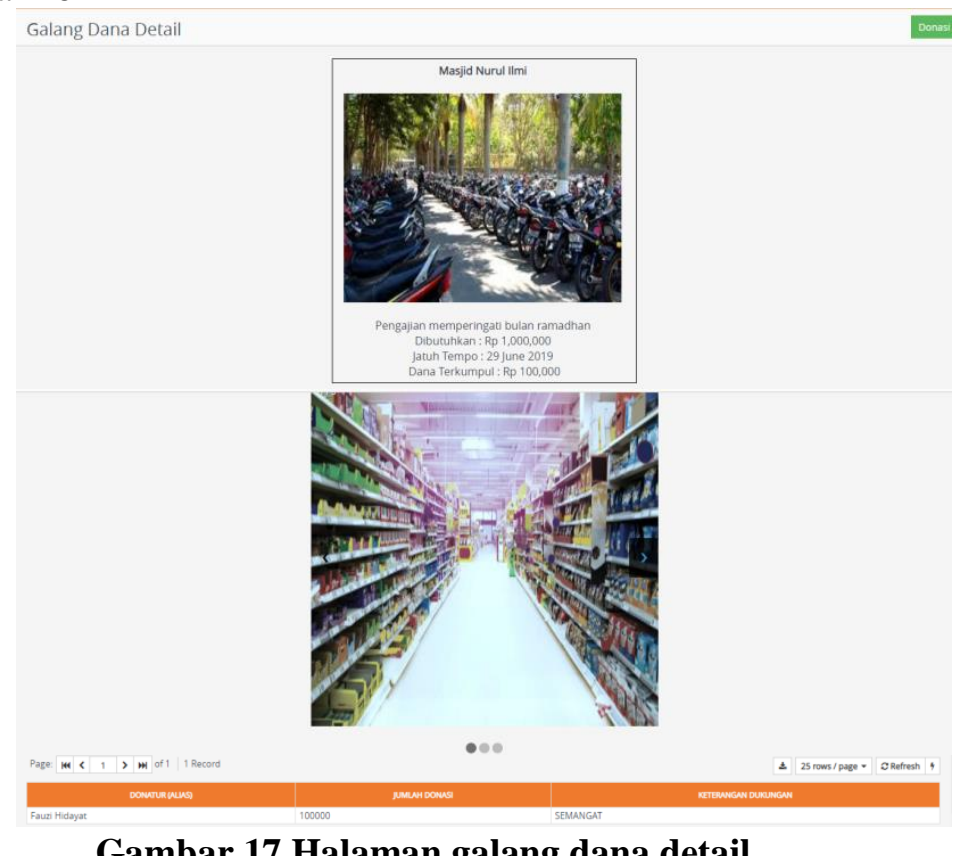

\section{Gambar 17 Halaman galang dana detail}

Pada halaman donasi ini jika donatur ingin melakukan donasi, maka donatur bisa memilih salah satu kebutuhan yang akan didanai dan menampilkan halaman galang dana detail. Pada halaman galang dana detail ditampilkan detail dari kebutuhan seperti keterangan kebutuhan, dana dibutuhkan, tanggal jatuh tempo kebutuhan akan berakhir, gambar detail dan dana yang terkumpul

Rengga Asmara, Sistem Informasi Pemeliharaan Tempat Ibadah Dalam Efektifitas Penyaluran Dana Sumbangan 
beserta siapa saja yang sudah melakukan donasi ke kebutuhan tersebut mulai dari nama donatur (alias), jumlah donasi, dan keterangan dukungan. Implementasi halaman galang dana detail dapat dilihat pada Gambar 17.

Jika donatur tetap ingin melanjutkan donasi ke kebutuhan yang sudah dipilih, maka donatur dapat mengklik button donasi di pojok kanan atas pada halaman galang dana detail untuk melakukan pendanaan. Pada halaman pendanaan akan ditampilkan keterangan kebutuhan, dana dibutuhkan serta tanggal jatuh tempo kebutuhan akan berakhir. Pada halaman ini juga donatur bisa memasukan jumlah donasi, keterangan dukungan, ingin pakai nama samaran atau tidak yang selanjutnya bisa mengklik button donasi pada halaman pendanaan kemudian akan diarahkan ke halaman payment gateway untuk ditunjukan nomor rekening beserta banknya guna melakukan transfer pendanaan sesuai jumlah donasi yang sudah diinputkan. Implementasi halaman pendanaan dapat dilihat pada Gambar 18.

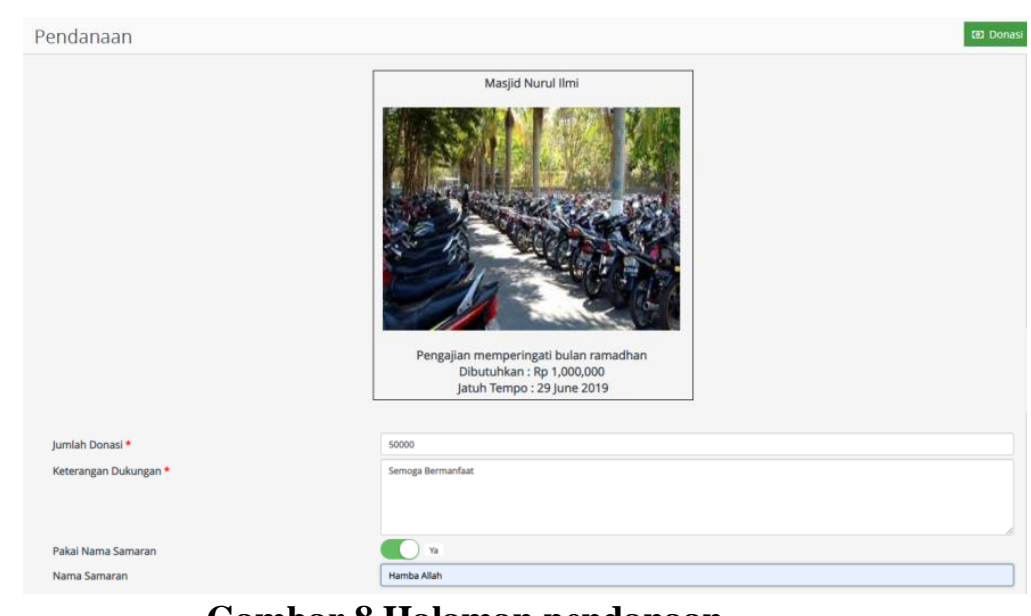

Gambar 8 Halaman pendanaan

\section{Implementasi Fitur Lihat Situasi Kondisi}

Situasi Kondisi

PENGAJUAN KEBUTUHAN SELESAI

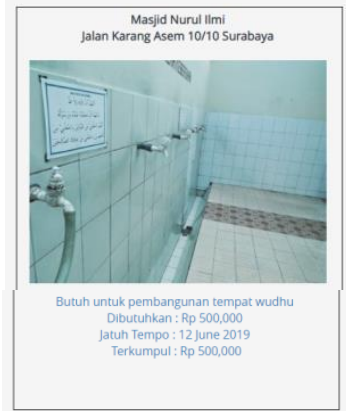

Gambar 9 Halaman pengajuan kebutuhan selesai

Halaman pengajuan kebutuhan selesai dapat diakses oleh donatur, pada halaman ini donatur dapat melihat beberapa pengajuan kebutuhan tempat ibadah yang sudah dikonfirmasi oleh admin yaitu kebutuhan tempat ibadah yang sudah selesai jatuh temponya dan dananya sudah dicairkan oleh admin diberikan ke mitra tempat ibadah yang bersangkutan. Pada halaman ini ditunjukkan nama tempat ibadah, alamat, keterangan kebutuhan, dana dibutuhkan, tanggal jatuh tempo kebutuhan berakhir serta dana yang terkumpul untuk kebutuhan tersebut. Implementasi halaman pengajuan kebutuhan selesai dapat dilihat pada Gambar 19. 


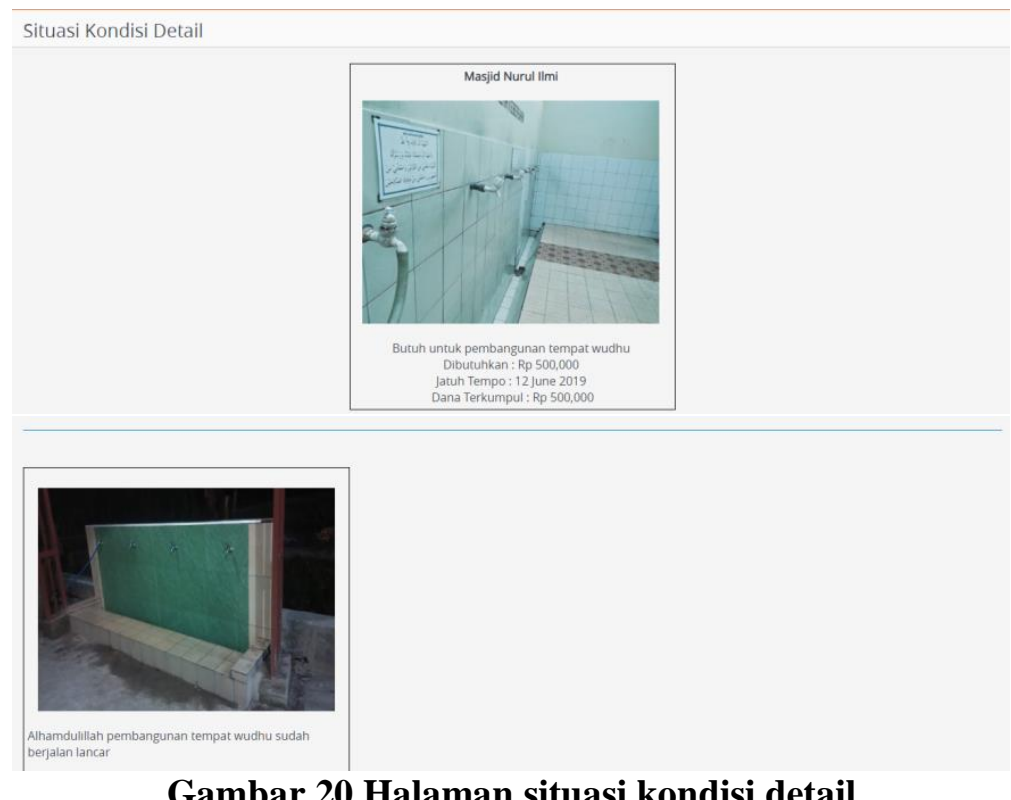

Gambar 20 Halaman situasi kondisi detail

Di halaman pengajuan kebutuhan selesai, donatur bisa memilih dan melihat situasi kondisi terbaru dari salah satu kebutuhan tempat ibadah yang sudah dikonfirmasi oleh admin. Halaman situasi kondisi detail akan muncul saat donatur memilih salah satu kebutuhan yang ada di halaman pengajuan kebutuhan selesai, pada halaman ini donatur dapat melihat situasi kondisi detail terbaru mulai dari keterangan situasi kondisi beserta gambar penunjangnya. Implementasi halaman situasi kondisi detail dapat dilihat pada Gambar 20.

\section{Implementasi Fitur Kategori Donatur}

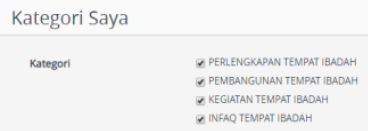

\section{Gambar 10 Halaman kategori donatur}

Halaman kategori donatur dapat diakses oleh donatur, pada halaman ini donatur bisa memilih kategori apa yang akan dipilih. Pemilihan kategori ini digunakan untuk memberitahu donatur yang bersangkutan jika ada kebutuhan baru yang diajukan ke dalam sistem sesuai dengan kategori yang dipiih, nantinya sistem akan memberi notifikasi lewat email bahwa ada kebutuhan baru yang sesuai kategori donatur. Implementasi halaman kategori donatur dapat dilihat pada Gambar 21.

D. Implementasi sistem pada user admin

1. Implementasi Fitur Konfirmasi Registrasi Mitra

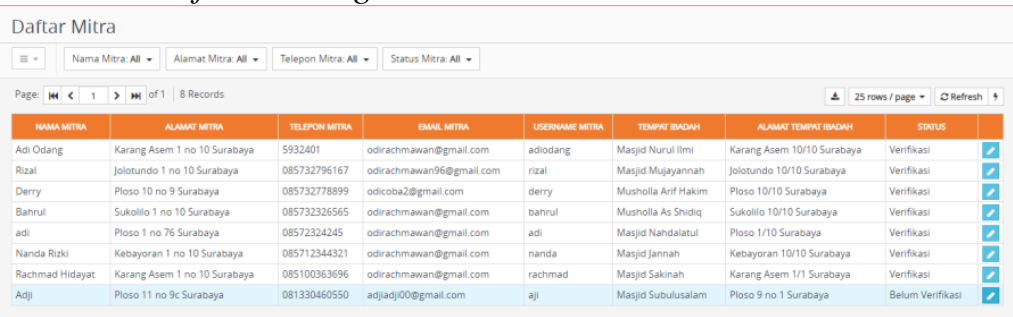

Gambar 211 Halaman daftar mitra

Halaman konfirmasi registrasi mitra merupakan halaman yang digunakan admin untuk mengkonfirmasi kebenaran dari mitra yang bersangkutan. Pada halaman ini ditampilkan daftar mitra baik yang sudah di konfirmasi maupun yang belum di konfirmasi. Tampilan halaman daftar mitra dapat dilihat pada Gambar 22.

Rengga Asmara, Sistem Informasi Pemeliharaan Tempat Ibadah Dalam Efektifitas Penyaluran Dana Sumbangan 


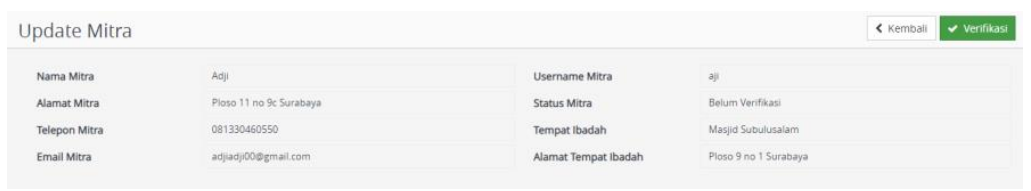

Gambar 12 Halaman konfirmasi registrasi mitra

Dari halaman daftar mitra, admin bisa memilih mitra mana yang statusnya belum diverifikasi. Lalu admin memilih mitra yang statusnya belum diverifikasi tersebut untuk di konfirmasi kebenarannya. Sebelum mengkonfirmasi mitra, admin benar-benar harus menjamin kebenaran suatu mitra tempat ibadah tersebut. Tampilan halaman konfirmasi registrasi mitra dapat dilihat pada Gambar 23.

\section{Implementasi Fitur Konfirmasi Kebutuhan}

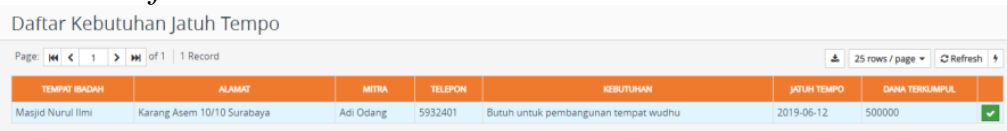

\section{Gambar 13 Halaman daftar kebutuhan jatuh tempo}

Halaman konfirmasi kebutuhan merupakan halaman yang digunakan admin untuk mengkonfirmasi kebutuhan mitra yang sudah selesai jatuh tempo. Pada halaman ini ditampilkan daftar kebutuhan mitra yang sudah lewat jatuh tempo. Tampilan halaman daftar kebutuhan jatuh tempo dapat dilihat pada Gambar 24.

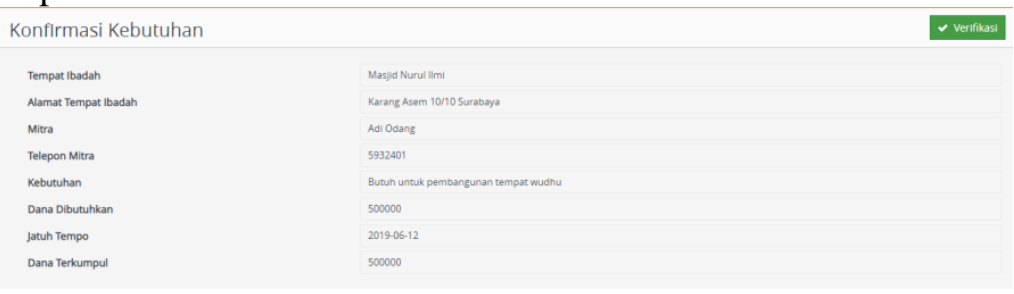

\section{Gambar 14 Halaman konfirmasi kebutuhan}

Dari halaman daftar kebutuhan jatuh tempo, admin bisa memilih kebutuhan mitra mana yang akan diverifikasi. Setelah memilih kebutuhan mitra, admin akan menghubungi mitra yang dipilih untuk memberikan dana yang tercatat dalam sistem kepada mitra yang bersangkutan. Tampilan halaman konfirmasi kebutuhan mitra dapat dilihat pada Gambar 25.

\section{Pengujian Sistem}

Pengujian sistem dibagi menjadi 2 yaitu berdasarkan Fungsionality(fungsionalitas) dan Usability (kebergunaan).

A. Fungsionality (Fungsionalitas)

Karakteristik pengujian fungsionalitas dibagi menjadi beberapa bagian berdasarkan subkarakteristiknya, dimana subkarakteristik suitability dan accuracy dilakukan menggunakan metode User Acceptance Test yang mengacu pada IEEE829 Test Plan. Pada pengujian karakteristik functionality, penguji akan menilai berdasarkan instrumen yang berupa test case menggunakan black box testing.

Dinyatakan bahwa setiap test case yang dilakukan dari pengujian, mendapatkan hasil yang sesuai dengan fungsinya. Metode analisis deskriptif digunakan dalam analisis dari pengujian functionality, berikut adalah perhitungan rata - rata presentase kalayakan sistem dari setiap item test case.

$$
\begin{gathered}
\text { presentase kelayakan }=\frac{\text { skor yang diobservasi }}{\text { skor yang diharapkan }} \times 100 \% \\
=\frac{53}{53} \times 100 \%=100 \%
\end{gathered}
$$


Dari hasil analisis deskriptif diatas, didapatkan hasil presentase dari sisi karakteristik functionality kelayakan system (subkarakteristik suitability dan accuracy) bernilai 100\% dan memiliki interpretasi Sangat Baik.

\section{B. Usability (Kebergunaan)}

Suatu website diciptakan untuk memenuhi kebutuhan pengguna. Oleh karena itu, maka Usability merupakan saalah satu faktor penting dalam pengembangan suatu website, sehingga kemudahan pengguna dalam menggunakan sistem harus lebih diutamakan. Pada pengujian usability, digunakan kuesioner yang berisi 19 pertanyaan mengenai computer software, yang dikembangkan oleh James R. Lewis. Hasil perhitungan dari kuesioner untuk menguji presentase kelayakan karakteristik usability dapat dilihat pada Tabel 1.

Tabel 1 Hasil Persentase Kelayakan Pengujian Usability

\begin{tabular}{|c|c|c|c|}
\hline $\begin{array}{c}\text { Item } \\
\text { Pertanyaan }\end{array}$ & Skor & $\begin{array}{c}\text { Skor } \\
\text { Diharapkan }\end{array}$ & \% Kelayakan \\
\hline 1 & 14 & 15 & $93 \%$ \\
\hline 2 & 13 & 15 & $86 \%$ \\
\hline 3 & 13 & 15 & $86 \%$ \\
\hline 4 & 13 & 15 & $86 \%$ \\
\hline 5 & 14 & 15 & $93 \%$ \\
\hline 6 & 13 & 15 & $86 \%$ \\
\hline 7 & 14 & 15 & $93 \%$ \\
\hline 8 & 13 & 15 & $86 \%$ \\
\hline 9 & 13 & 15 & $86 \%$ \\
\hline 10 & 13 & 15 & $86 \%$ \\
\hline 11 & 14 & 15 & $93 \%$ \\
\hline 12 & 14 & 15 & $93 \%$ \\
\hline 13 & 13 & 15 & $86 \%$ \\
\hline 14 & 14 & 15 & $93 \%$ \\
\hline 15 & 13 & 15 & $86 \%$ \\
\hline 16 & 13 & 15 & $86 \%$ \\
\hline 17 & 13 & 15 & $86 \%$ \\
\hline 18 & 13 & 15 & $86 \%$ \\
\hline 19 & 13 & 15 & $86 \%$ \\
\hline \multicolumn{3}{|c|}{ Rata-Rata } & $88 \%$ \\
\hline
\end{tabular}

Dari hasil analisis deskriptif didapatkan hasil untuk pengujian usability mendapatkan presentase kelayakan $\mathbf{8 8 \%}$ yang masuk dalam kategori Sangat Layak.

Poin-poin terendah pada hasil pengujian dan analisis dari hasil usability sistem dapat dilihat yaitu, yang berada pada angka 86\% yaitu poin pertanyaan tersebut mengenai peringatan kesalahan yang ada pada sistem, kemudahan pada tampilan sistem, dan ketepatan fungsi seperti yang user inginkan. Penjelasan pada poin pertama yaitu, peringatan kesalahan yang ada pada sistem dinilai cukup layak dikarenakan beberapa kesalahan tidak diberikan tampilan peringatan dengan jelas pada user, sehingga user kurang memahami penyebabab kesalahan dan cara mengatasinya.

\section{KESIMPULAN}

Berdasarkan hasil analisa serta uji coba yang dijelaskan pada bab sebelumnya, maka dapat diperoleh beberapa kesimpulan yaitu aplikasi sistem informasi pemeliharaan tempat ibadah dalam efektifitas penyaluran dana sumbangan inimendapatkan presentase kelayakan $100 \%$ dalam hal fungsionalitas dan $88 \%$ dalam hal kebergunaan yang termasuk dalam kategori sangat layak dan sangat baik dalam membantu dalam proses pengelolaan pengumpulan dana. Dengan adanya sistem ini baik mitra tempat ibadah maupun donatur bisa dengan mudah mencari dana untuk tempat ibadah maupun menyalurkan donasi secara tepat sesuai kebutuhan tempat ibadah yang paling membutuhkan.

Rengga Asmara, Sistem Informasi Pemeliharaan Tempat Ibadah Dalam Efektifitas Penyaluran Dana Sumbangan 


\section{REFERENSI}

[1] A. Aditya et al., "ANALISA DAN PERANCANGAN WEBSITE CROWDFUNDING DOMPET," vol. 4, no. 2, pp. 101-109, 2018.

[2] S. H. E. Wulandari, "Aplikasi Transparansi Sumbangan Masyarakat Berbasis Web," Assoc. Inf. Syst. - Indones. chapter, vol. 2, pp. 1-14, 2018.

[3] A. Handojo and A. Wibowo, "Aplikasi Crowdfunding Sebagai Perantara Penggalangan Dana Berbasis Website dan Facebook Application," Komputer, vol. 2, no. Jaringan Komputer, pp. 1$5,2012$.

[4] Bin Ladjamudin, "Analisis dan Desain Sistem Informasi," Anal. dan Desain Sist. Inf., 2013.

[5] J. O'Brien, "Business information systems," in Introducing Information Management: The Business Approach, 2014.

[6] T. E. Young, "The Everything Guide to Crowdfunding: Learn how to use social media for smallbusiness funding.," Avon, MA, United States Am. Adams Media., 2012.

[7] J. Morduch, "The microfinance promise," J. Econ. Lit., 1999.

[8] M. K. Poetz and M. Schreier, "The value of crowdsourcing: Can users really compete with professionals in generating new product ideas?," J. Prod. Innov. Manag., 2012.

[9] J. Hemer, "A snapshot on crowdfunding," Enconstor, 2011.

[10] D. Setiawan, "Pengertian HTML," Buku Sakti pemrograman web. 2016.

[11] A. Zakir, "IMPLEMENTASI TEKNOLOGI FRAMEWORK YII PADA APLIKASI BERBASIS WEB," InfoTekJar (Jurnal Nas. Inform. dan Teknol. Jaringan), 2017.

[12] D. P. Pop and A. Altar, "Designing an MVC model for rapid web application development," in Procedia Engineering, 2014.

[13] J. Krause and J. Krause, "CSS: Cascading Style Sheets," in Introducing Web Development, 2016, pp. 65-86.

[14] A. R. K. Lena, "Pengertian PHP dan MySQL," Ilmu Teknol. Inf., 2015.

[15] International Organization For Standardization, "ISO/IEC 9126:2001," Software engineering Product quality, vol. 2, no. 1. pp. 1-25, 2001. 